\title{
Estimation of heterosis in yield and yield attributing traits in single cross hybrids of maize
}

\author{
${ }^{1}$ Hari Prasad Sharma*, ${ }^{2}$ Krishna Hari Dhakal, ${ }^{2}$ Raju Kharel \\ and ${ }^{1}$ Jiban Shrestha \\ ${ }^{1}$ National Maize Research Program, Rampur, Chitwan, Nepal \\ ${ }^{2}$ Agriculture and Forestry University, Rampur, Chitwan, Nepal
}

*Corresponding author email: harisharma.ag@gmail.com

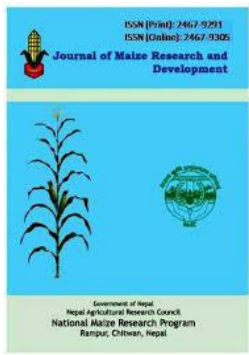

Received: September 2016; Revised: October 2016; Accepted: November 2016

\begin{abstract}
A field experiment was conducted at National Maize Research Program, Rampur, Chitwan, Nepal during winter season from $6^{\text {th }}$ October, 2015 to $5^{\text {th }}$ March 2016 to estimate different heterosis on single cross maize hybrids. Thirteen maize hybrids were tested randomized complete block design with three replications. Hybrid namely RML-98/RL-105 gave the highest standard heterosis (57.5\%) for grain yield over CP-666 followed by RML-4/NML-2 (32.6\%), RML-95/RL-105 (29\%) and RML-5/RL-105 (20.6\%). The hybrid RML-98/RL-105 produced the highest standard heterosis $(75.1 \%)$ for grain yield over Rajkumar followed by RML-4/NML2(50.2\%), RML-95/RL-105(46.6\%), RML-5/RL-105 and (35.7\%). Mid and better parent heterosis were significantly higher for yield and yield attributes viz. ear length, ear diameter, no of kernel row per ear, no of kernel per row and test weight. The highest positive mid-parent heterosis for grain yield was found in RML-98/RL-105 followed by RML-5/RL-105, RML95/RL-105, and RML-4/NML-2. For the grain yield the better parent heterosis was the highest in RML-98/RL-105, followed by RML-5/RL-105, RML-95/RL-105, and RML-4/NML-2. These results suggested that maize production can be maximized by cultivating hybrids namely RML98/RL-105, RML-5/RL-105, RML-95/RL-105, and RML-4/NML-2 .
\end{abstract}

Key words: Maize, single cross hybrid, heterosis, and grain yield.

Correct citation: Sharma, H.P., Dhakal, K.H., Kharel, R., \& Shrestha, J. (2016). Estimation of heterosis in yield and yield attributing traits in single cross hybrids of maize. Journal of Maize Research and Development, 2 (1), 123-132, doi: http://dx.doi.org/10.3126/jmrd.v2i1.16223

\section{INTRODUCTION}

Maize (Zea mays L.) is the world's widely grown cereal and primary staple food crop in many developing countries. In Nepal, after rice maize is second most important crop in terms of area and production. The area and productivity of this crop in Nepal is 8.823 million hectare and $2.43 \mathrm{t} \mathrm{ha}^{-1}$, respectively $(\mathrm{MoAD}, 2015)$. It is also an important feed ingredient for poultry and 
livestock. Yan et al., (2011) noticed that more than half of the increased demand in the world food in term of cereals as a whole will be produced from maize farmers and consumers. There are many constraints in maize production one of them is lack of high yielding hybrids. The numbers of maize hybrids developed in Nepal are insufficient i.e. five hybrids released in 13 years duration and those released so far are not also competitive. The dependency over imported hybrid maize seed increased every year due to unavailability of competitive hybrid cultivars within the country and underdeveloped seed industries (Gurung et al., 2011). Thirty-two hybrids of 14 seed companies have been registered in National Seed Board (Koirala et al., 2013). In this context, as the hybrid maize area has been growing extensively in Terai and partly in mid-hill districts, the commercial seed companies are the major source of seed. Hybrid maize seed marketing is flourishing every year but limited commercial hybrids are suited to cultivation owing to existing diverse agro-ecological regime of the country. Since 250 years top innovations in modern agriculture has begun with heterosis discovery in plant crosses (Malik et al., 2004). Heterosis (hybrid vigor) is the enhancement in size, growth, fertility and yield in progeny compared to parents. Hallauer and Miranda (1988) manifested that heterosis depends on the genetic divergence of two parental varieties; also genetic divergence of the parents is inferred from the heterotic patterns manifested in a series of cross combination. As compared to existing cultivars the new maize hybrid should be better for grain yield and other economic traits. The determination of heterosis is important for development of superior hybrids. Such type of research was not sufficient therefore this study was conducted to estimate heterosis in single cross hybrids.

\section{MATERIALS AND METHODS}

The experiment was carried out at the research farm of National Maize Research Program (NMRP), Rampur, Chitwan, Nepal from first week of 6 October, 2015 to 5 March, 2016. The mean maximum temperature $27.32^{\circ} \mathrm{C}$ and minimum temperature $14.33^{\circ} \mathrm{C}$ were recorded. Maximum temperature ranged from $22.16^{\circ} \mathrm{C}$ to $32.4^{\circ} \mathrm{C}$. The minimum temperature ranged from $8.76^{\circ} \mathrm{C}$ to $24.08^{\circ} \mathrm{C}$. Highest rainfall $(42.5 \mathrm{~mm})$ recorded during October 2015 , the lowest rainfall $(4.66 \mathrm{~mm})$ during January. The total rainfall during crop growing season was $95.66 \mathrm{~mm}$. The experiment was laid out in Randomized Complete Block Design (RCBD) with three replications consisting of 11 single cross hybrids and 2 check hybrids. The individual plot size was $3.6 \mathrm{~m}^{2}(2$ rows of $3 \mathrm{~m}$ length) and spacing was of $60 \mathrm{~cm} \times 25 \mathrm{~cm}$. The soil texture was sandy loam and slightly acidic. The FYM @ 10 t/ha long with 120:64:40 kg NPK ha ${ }^{-1}$ was applied in the experiments. Half nitrogen, full dose of phosphorous and potash (60:60:40 $\mathrm{kg} \mathrm{N}_{2}, \mathrm{P}_{2} \mathrm{O}_{5}$ and $\mathrm{K}_{2} \mathrm{O}$ per ha) was applied during sowing. Remaining dose of nitrogen is splitted into two parts and topdressed during 30 DAS and 45 DAS. Grain yield per hectare was calculated by converting yield per plot into grain yield per hectare. Grain yield was obtained by adjusting the grain moisture at $15 \%$ and converted to the grain yield per hectare with the help of the formula adopted by Carangal et al. (1971) and Shrestha et al. (2015). 
Journal of Maize Research and Development (2016) 2 (1): 123-132

ISSN: 2467-9291 (Print), 2467-9305 (Online)

DOI: http://dx.doi.org/10.3126/jmrd.v2i1.16223

Table 1. List of hybrids used in the experiment.

\begin{tabular}{lll}
\hline SN & Hybrids & Parentage lines \\
\hline 1 & RML-4/RML-17 & CA00326/CML-287 \\
2 & RML-95/RML-96 & PUTU-17/AG-27 \\
3 & RML-32/RML-17 & CA00320/CML-287 \\
4 & RML-86/RML-96 & PUTU-20/AG-27 \\
5 & RML-5/RL-105 & CA00314/UPAHAR-B-20-2-4-1-1 \\
6 & RML-95/RL-105 & PUTU-17/UPAHAR-B-20-2-4-1-1 \\
7 & RML-115/RML-96 & PUTU-17/AG-27 \\
8 & RML-153/RL-105 & POOL-21-12-1-2-1-1-1/UPAHAR-B-20-2-4-1-1 \\
9 & RML-85/RL-105 & PUTU-14/UPAHAR-B-20-2-4-1-1 \\
10 & RML-98/RL-105 & L-3/UPAHAR-B-20-2-4-1-1 \\
11 & Rajkumar & - \\
12 & RML-4/NML-2(Rampur Hybrid-2) & CA00326/CML-430 \\
13 & CP-666 & - \\
\hline
\end{tabular}

Percent standard heterosis was calculated for using formula as suggested by Falconer and Mackay (1996). This was computed as percentage increase or decrease of the cross performances over the best standard check as: Standard heterosis refers to the superiority of $F_{1}$ over the standard commercial check variety. It is also called as economic heterosis or useful heterosis and calculated by using formula.

$$
\text { Standard heterosis }(\%)=\frac{F 1-\text { Check variety }}{\text { Check variety }} \times 100
$$

Mid parent and better parent heterosis was estimated using below formula;

$$
\begin{aligned}
\text { Mid parent heterosis }(\%) & =\frac{F 1-\text { Mid parent }}{\text { Mid parent }} \times 100 \\
\text { Better parent heterosis }(\%) & =\frac{F 1-\text { Better parent }}{\text { Better parent }} \times 100
\end{aligned}
$$

The statistical package MSTAT-C was applied to analyze data (Russel \& Eisensmith, 1983). The significant differences between treatments were determined at probability level of 0.01 or 0.05 using least significant difference (LSD) test.

\section{RESULTS AND DISCUSSION}

Standard heterosis of tested genotypes ranged from -8.6 to $90.4 \%$ (Table 2). The positive standard heterosis was shown by most of hybrids for grain yield. Hybrid namely RML-98/RL105 had the highest standard heterosis of $57.5 \%$ over CP-666 followed by RML-4/NML2(32.6\%) and RML-95/RL-105(29\%) and RML-5/RL-105 (20.6\%) respectively. The RML98/RL-105 had the highest standard heterosis (75.1\%) over Rajkumar followed by RML-5/RL105 (35.7\%), RML-4/NML-2(50.2\%) and RML-95/RL-105(46.6\%) respectively. Hybrid namely RML-98/RL-105, RML-5/RL-105, RML-4/NML-2, RML-95/RL-105 were superior hybrids, which manifested $>15 \%$ standard heterosis over check hybrids (CP-666 and Rajkumar). Rosa et al. (2002) were reported similar findings. In this study there was significant level of heterosis for the yield. Semel et al. (2006) estimated the better-parent heterosis primarily for reproductive traits related to yield. 
Journal of Maize Research and Development (2016) 2 (1): 123-132

ISSN: 2467-9291 (Print), 2467-9305 (Online)

DOI: http://dx.doi.org/10.3126/jmrd.v2i1.16223

Table 2. Heterosis for grain yield of single cross hybrids evaluated at NMRP Rampur Chitwan in 2015/16 during winter season.

\begin{tabular}{|c|c|c|c|c|c|}
\hline \multirow[t]{2}{*}{$\mathrm{SN}$} & \multirow[t]{2}{*}{ Hybrids } & \multicolumn{2}{|c|}{ Standard (\%) } & \multirow{2}{*}{$\begin{array}{l}\text { Better } \\
\text { parent }(\%)\end{array}$} & \multirow{2}{*}{$\begin{array}{l}\text { Mid parent } \\
(\%)\end{array}$} \\
\hline & & CP-666 & Rajkumar & & \\
\hline 1 & RML-4/RML-17 & 20.9 & 33.6 & 185 & 274 \\
\hline 2 & RML-95/RML-96 & -1.4 & 9.6 & 178 & 175 \\
\hline 3 & RML-32/RML-17 & -4.4 & 11.5 & 138 & 216 \\
\hline 4 & RML-86/RML-96 & 12.5 & 27.2 & 222 & 251 \\
\hline 5 & RML-5/RL-105 & 20.6 & 35.7 & 439 & 580 \\
\hline 6 & RML-95/RL-105 & 29 & 46.6 & 371 & 457 \\
\hline 7 & RML-115/RML-96 & 16.2 & 36.1 & 210 & 224 \\
\hline 8 & RML-153/RL-105 & 20.6 & 36.3 & 170 & 273 \\
\hline 9 & RML-85/RL- 105 & 19.6 & 35.5 & 222 & 320 \\
\hline 10 & RML-98/RL-105 & 57.5 & 30.6 & 476 & 590 \\
\hline \multirow[t]{5}{*}{11} & RML-4/NML-2 & 32.6 & 50.2 & 271 & 353 \\
\hline & $\mathrm{P}$ value & 0.542 & 0.883 & 223.6 & 223.6 \\
\hline & F test & $\mathrm{ns}$ & ns & $\mathrm{ns}$ & ns \\
\hline & $\mathrm{LSD}_{0.05}$ & 51.4 & 32.76 & 50.1 & 50.1 \\
\hline & $\mathrm{CV}, \%$ & 148.4 & 95.7 & 50.1 & 33.3 \\
\hline
\end{tabular}

Table 3 revealed that RML-5/RL-105 had the highest better parent heterosis in ear length (89.3\%) followed by RML-95/RL-105(85.95\%) and RML-98/RL-105(85.8\%). Similarly RML5/RL-105 had maximum heterosis in ear length (105.5\%) followed by RML-98/RL-105(101.3\%) and RML-95/RL-105(96.8\%) over mid parent. Genotype RML-153/RL-105 had the highest heterosis in ear length (17.3\%) followed by RML-5/RL-105(16\%) and RML-98/RL-105(15.2\%) over CP-666. Similarly, genotype RML-153/RL-105 had the maximum heterosis in ear length (24.5\%) followed by RML-5/RL-105(22.6\%) and RML-98/RL-105(21.8\%) over Rajkumar. Genotype RML-153/RL-105, RML-5/RL-105, RML-98/RL-105 and RML-5/RL-105 had standard heterosis $>15 \%$ over Rajkumar and CP-666 similarly those genotypes had > 85\% heterosis over mid and better parent heterosis. Abdel-moneam et al.(2009) reported that positive significant heterosis values over both their mid and better parents for ear length in maize populations.

Table 4 showed that RML-95/RL-105 had the highest heterobeltiosis in ear diameter (112.3\%) followed by RML-4/RML-17(108.6\%). Likewise, the maximum heterosis in ear diameter was found in RML-5/RL-105(135.8\%) followed by RML-95/RL-105(133.7\%). The maximum heterosis was recorded in RML-115/RL-96 (112.3\%) in ear diameter followed by RML-4/RML-17(47.81\%) over CP-666. RML-115/RL-96 had obtained highest heterosis in ear diameter $(59.33 \%)$ and same reasult was also found in RML-4/RML-17(58.89\%) over Rajkumar. Genotypes RML-115/RL-96, RML-4/RML-1, RML-115/RL-96 and RML-4/RML-17 had standard heterosis > 47\% over Rajkumar and CP-666 similarly RML-95/RL-105, RML-4/RML- 
Journal of Maize Research and Development (2016) 2 (1): 123-132

ISSN: 2467-9291 (Print), 2467-9305 (Online)

DOI: http://dx.doi.org/10.3126/jmrd.v2i1.16223

17 and RML-5/RL-105 had mid and better parent heterosis > 108\%. Similar reasults were observed by Semel et al. (2006).

Table 3. Heterosis for ear length of single cross hybrids evaluated at NMRP, Rampur, Chitwan in 2015/16 during winter season

\begin{tabular}{|c|c|c|c|c|c|}
\hline \multirow[t]{2}{*}{$\mathrm{SN}$} & \multirow[t]{2}{*}{ Hybrids } & \multicolumn{2}{|c|}{ Standard (\%) } & \multirow{2}{*}{$\begin{array}{c}\text { Better parent } \\
(\%)\end{array}$} & \multirow{2}{*}{$\begin{array}{c}\text { Mid parent } \\
(\%)\end{array}$} \\
\hline & & CP-666 & Rajkumar & & \\
\hline 1 & RML-4/RML-17 & 12 & 18 & 39.9 & 60.8 \\
\hline 2 & RML-95/RML-96 & -2.1 & 3.1 & 28.8 & 34.8 \\
\hline 3 & RML-32/RML-17 & 11 & 17.8 & 39.2 & 64.8 \\
\hline 4 & RML-86/RML-96 & 7.7 & 13.9 & 41.6 & 55.4 \\
\hline 5 & RML-5/RL-105 & 16 & 22.6 & 89.3 & 105.5 \\
\hline 6 & RML-95/RL-105 & 10.9 & 16.8 & 85.9 & 96.8 \\
\hline 7 & RML-115/RML-96 & -10.1 & -6 & 21.5 & 30.5 \\
\hline 8 & RML-153/RL-105 & 17.3 & 24.5 & 11.9 & 48.8 \\
\hline 9 & RML-85/RL- 105 & 7.3 & 13.3 & 41.6 & 67.9 \\
\hline 10 & RML-98/RL-105 & 15.2 & 21.8 & 85.8 & 101.3 \\
\hline \multirow[t]{5}{*}{11} & RML-4/NML-2 & 7.7 & 13.6 & 59.8 & 72 \\
\hline & $\mathrm{P}$ value & 0.126 & 0.144 & 0.287 & 0.006 \\
\hline & $F$ test & ns & $\mathrm{ns}$ & $\mathrm{ns}$ & $* *$ \\
\hline & $\mathrm{LSD}_{0.05}$ & 17.94 & 20.08 & 69.4 & 38.92 \\
\hline & $\mathrm{CV}, \%$ & 124.5 & 81.3 & 82.2 & 34 \\
\hline
\end{tabular}

Table 4. Heterosis for ear diameter of single cross hybrids evaluated at NMRP Rampur Chitwan in 2015/16 during winter season

\begin{tabular}{|c|c|c|c|c|c|}
\hline \multirow[b]{2}{*}{$\mathrm{SN}$} & \multirow[b]{2}{*}{ Hybrids } & \multicolumn{2}{|c|}{ Standard $(\%)$} & \multirow{2}{*}{ Better parent (\%) } & \multirow{2}{*}{$\begin{array}{l}\text { Mid parent } \\
(\%)\end{array}$} \\
\hline & & CP-666 & Rajkumar & & \\
\hline 1 & RML-4/RML-17 & 47.81 & 58.89 & 108.6 & 117.2 \\
\hline 2 & RML-95/RML-96 & 39.39 & 49.85 & 86.1 & 85.2 \\
\hline 3 & RML-32/RML-17 & 37.31 & 47.93 & 93.9 & 132.9 \\
\hline 4 & RML-86/RML-96 & 41.26 & 52.22 & 88 & 104.8 \\
\hline 5 & RML-5/RL-105 & 38.79 & 49.48 & 101.2 & 135.8 \\
\hline 6 & RML-95/RL-105 & 47.14 & 58.59 & 112.3 & 133.7 \\
\hline 7 & RML-115/RML-96 & 47.98 & 59.53 & 96.6 & 103.1 \\
\hline 8 & RML-153/RL-105 & 40.17 & 51.16 & 60.6 & 94.8 \\
\hline 9 & RML-85/RL- 105 & 42.53 & 53.42 & 92.9 & 115.8 \\
\hline 10 & RML-98/RL-105 & 44.17 & 54.96 & 95.8 & 121.5 \\
\hline
\end{tabular}


Journal of Maize Research and Development (2016) 2 (1): 123-132

ISSN: 2467-9291 (Print), 2467-9305 (Online) DOI: http://dx.doi.org/10.3126/jmrd.v2i1.16223

\begin{tabular}{llllll}
11 & RML-4/NML-2 & 43.17 & 54.07 & 93.9 & 101.1 \\
\hline P value & 0.105 & 0.103 & 0.355 & 0.039 \\
F test & $\mathrm{ns}$ & $\mathrm{ns}$ & $\mathrm{ns}$ & $*$ \\
LSD $_{0.05}$ & 7.984 & 8.549 & 36.54 & 31.54 \\
$\mathrm{CV}, \%$ & 11 & 9.4 & 22.9 & 16.4 \\
\hline
\end{tabular}

Table 5 revealed that RML-5/RL-105 had the highest heterobeltiosis in number of kernel row per ear (44.8\%) followed by RML-4/RML-17(42.2\%). Correspondingly, RML-32/RML-17 had the highest heterosis in no of kernel row per ear (81.4\%) and RML-5/RL-105 had (52.2\%). Genotype RML-85/RL-105 had observed highest heterosis in no of kernel row per ear (18.5\%) followed by RML-95/RL-105(18.5\%) over CP-666. Genotype RML-95/RL-105 had the maximum heterosis in no of kernel row per ear $(23.8 \%)$ same reasult found in RML-85/RL105(23.8\%) over Rajkumar. Genotype RML-85/RL-105, RML-95/RL-105, RML-86/RML-96 and RML-4/NML-2 had standard heterosis >19\% over Rajkumar and CP-666. Equally, RML5/RL-105, RML-4/RML-17, RML-32/RML-17and RML-98/RL-105 had > 42\% mid and better parent heterosis in number of kernel row per ear. The heterosis was from $18.2 \%$ to $34.5 \%$ in temperate sub-tropical and tropical maize germplasm obtained by (Mallik et al., 2004).

Table 5. Heterosis for No of kernel row per ear of single cross hybrids at NMRP Rampur Chitwan in 2015/16 during winter season.

\begin{tabular}{|c|c|c|c|c|c|}
\hline \multirow[t]{2}{*}{$\mathrm{SN}$} & \multirow[t]{2}{*}{ Hybrids } & \multicolumn{2}{|c|}{ Standard $(\%)$} & \multirow{2}{*}{$\begin{array}{l}\text { Better } \\
\text { parent }(\%)\end{array}$} & \multirow{2}{*}{$\begin{array}{l}\text { Mid parent } \\
(\%)\end{array}$} \\
\hline & & CP-666 & Rajkumar & & \\
\hline 1 & RML-4/RML-17 & 9.5 & 14.3 & 42.2 & 34 \\
\hline 2 & RML-95/RML-96 & 9.5 & 14.3 & 14.3 & 17.2 \\
\hline 3 & RML-32/RML-17 & 4.8 & 9.5 & 36.7 & 81.4 \\
\hline 4 & RML-86/RML-96 & 14.3 & 19 & 19 & 28.7 \\
\hline 5 & RML-5/RL-105 & 9.5 & 14.3 & 44.8 & 55.2 \\
\hline 6 & RML-95/RL-105 & 18.5 & 23.8 & 31 & 44.4 \\
\hline 7 & RML-115/RML-96 & 14.3 & 19 & 19 & 35.5 \\
\hline 8 & RML-153/RL-105 & 9.5 & 14.3 & 15.9 & 30.5 \\
\hline 9 & RML-85/RL- 105 & 18.5 & 23.8 & 39 & 49.5 \\
\hline 10 & RML-98/RL-105 & 9.5 & 14.3 & 27 & 38 \\
\hline \multirow[t]{5}{*}{11} & RML-4/NML-2 & 9.5 & 19 & 14.3 & 25.3 \\
\hline & $\mathrm{P}$ value & 0.451 & 0.203 & 0.122 & 0.009 \\
\hline & F test & ns & ns & ns & $* *$ \\
\hline & $\mathrm{LSD}_{0.05}$ & 12.33 & 10.63 & 25.61 & 27.74 \\
\hline & $\mathrm{CV}, \%$ & 62.5 & 37 & 54.6 & 40.8 \\
\hline
\end{tabular}


Table 6 showed that RML-85/RL-105 had the highest better parent heterosis in no of kernel per row (175\%) followed by RML-98/RL-105(170\%) similarly the genotype RML-5/RL105 had the highest heterosis in no of kernel per row (223.3\%) followed by RML-98/RL105(203.8\%). Similarly, RML-98/RL-105 had the highest heterosis in no of kernel per row (38.39\%) followed by RML-5/RL-105(38.7\%) over CP-666. The maximum heterosis in no of kernel per row had found in RML-98/RL-105 (35.2\%) followed by RML-85/RL-105(34.4\%) over Rajkumar. In Spanish maize populations Ordas (1991) and Ali et al. (2014) reported similar results. Flint Garcia et al. (2009) evaluated heterosis of hybrid maize and found similar results.

Table 6. Heterosis for no of kernel per row of single cross hybrids at NMRP Rampur Chitwan during in 2015/16 during winter season.

\begin{tabular}{llllll}
\hline \multirow{2}{*}{ SN } & Hybrids & \multicolumn{3}{c}{ Standard (\%) } & Better \\
parent (\%) & $\begin{array}{l}\text { Mid } \\
(\%)\end{array}$ & parent \\
\cline { 3 - 5 } & & CP-666 & Rajkumar & 117 & 116.7 \\
2 & RML-4/RML-17 & 28.2 & 24.8 & 41 & 42 \\
3 & RML-95/RML-96 & 9.3 & 6.3 & 115 & 201.9 \\
4 & RML-32/RML-17 & 28.8 & 25.9 & 57 & 80.3 \\
5 & RML-86/RML-96 & 21.8 & 18.5 & 156 & 223.3 \\
6 & RML-5/RL-105 & 38.7 & 34.8 & 91 & 144 \\
7 & RML-95/RL-105 & 33 & 29.8 & 54 & 95.2 \\
8 & RML-115/RML-96 & 19.4 & 16.6 & 25 & 82.9 \\
9 & RML-153/RL-105 & 32.9 & 28.9 & 175 & 197.9 \\
10 & RML-85/RL- 105 & 34.4 & 30.4 & 170 & 203.8 \\
11 & RML-98/RL-105 & 38.9 & 35.2 & 71 & 91.5 \\
\hline & RML-4/NML-2 & 24.2 & 20.9 & 0.072 & $<.001$ \\
& P value & 0.050 & 0.050 & ns & $* *$ \\
& F-test & $*$ & $*$ & 107.1 & 65.18 \\
& LSD 0.05 & 17.57 & 16.83 & 64.4 & 28.5 \\
\hline
\end{tabular}

Table 7 showed that RML-95/RL-105 had the highest heterobeltiosis in thousand kernel weight (118.8\%) followed by RML-85/RL-105 (117.9\%) similarly RML-115/RML-96 showed highest heterosis in thousand kernel weight (123.9\%) followed by RML-86/RML-96 (111.6\%). In thousand kernel weight the highest heterosis was recorded in RML-98/RL-105 (18.6\%) followed by RML-153/RL-105(13.7\%) over CP-666. Similarly RML-98/RL-105 had the highest heterosis in thousand kernel weight (13.8\%) followed by RML-153/RML-105(9.8\%) over Rajkumar. Genotypes RML-98/RL-105, RML-153/RL-105, RML-4/RML-17 and RML86/RML-96 had > 8\% standard heterosis over Rajkumar and CP-666 similarly RML-95/RL-105, RML-115/RML-96, RML-86/RML-96 and RML-85/RL-105 had > 111\% mid and better parent heterosis. Hybrid RML-98/RL-105 manifested highest better parent heterosis in grain yield (476\%) followed by RML-5/RL-105(439\%) and RML-95/RL-105(371\%) respectively. Gadad 
Journal of Maize Research and Development (2016) 2 (1): 123-132

ISSN: 2467-9291 (Print), 2467-9305 (Online)

DOI: http://dx.doi.org/10.3126/jmrd.v2i1.16223

(2003) found that significant and positive standard heterosis for test weight in inter-varietal crosses of maize. Gurung (2006) reported -22 to $63.1 \%$ heterosis for grain yield in maize populations. Shrestha et al. (2011) also reported that there was more than $40 \%$ standard heterosis in single cross hybrids of maize.

Table 7. Heterosis for test weight of single cross hybrids at NMRP Rampur Chitwan in 2015/16 during winter season

\begin{tabular}{|c|c|c|c|c|c|}
\hline \multirow[t]{2}{*}{$\mathrm{SN}$} & \multirow[t]{2}{*}{ Hybrids } & \multicolumn{2}{|c|}{ Standard (\%) } & \multirow{2}{*}{$\begin{array}{l}\text { Better parent } \\
(\%)\end{array}$} & \multirow{2}{*}{$\begin{array}{l}\text { Mid parent } \\
(\%)\end{array}$} \\
\hline & & CP-666 & Rajkumar & & \\
\hline 1 & RML-4/RML-17 & 12.2 & 8.3 & 92.9 & 83 \\
\hline 2 & RML-95/RML-96 & 5.7 & 2.1 & 93 & 100 \\
\hline 3 & RML-32/RML-17 & 3.2 & 0.4 & 77.8 & 76.1 \\
\hline 4 & RML-86/RML-96 & 10.4 & 7.3 & 103.1 & 111.6 \\
\hline 5 & RML-5/RL-105 & 12.2 & 7.8 & 84.5 & 109.3 \\
\hline 6 & RML-95/RL-105 & 10.9 & 6.8 & 118.8 & 108.7 \\
\hline 7 & RML-115/RML-96 & 14 & 10 & 108.1 & 123.9 \\
\hline 8 & RML-153/RL-105 & 13.7 & 9.8 & 87 & 95.2 \\
\hline 9 & RML-85/RL- 105 & 8.7 & 4.9 & 117.9 & 105.2 \\
\hline 10 & RML-98/RL-105 & 18.6 & 13.8 & 96.1 & 102.7 \\
\hline \multirow[t]{5}{*}{11} & RML-4/NML-2 & 5.2 & 1.1 & 81.5 & 75.8 \\
\hline & $\mathrm{P}$ value & 0.721 & 0.719 & 0.365 & 0.205 \\
\hline & F test & ns & $\mathrm{ns}$ & ns & ns \\
\hline & $\mathrm{LSD}_{0.05}$ & 15.95 & 14.62 & 38.28 & 36.83 \\
\hline & $\mathrm{CV}, \%$ & 89.7 & 130.4 & 23.3 & 21.8 \\
\hline
\end{tabular}

\section{CONCLUSION}

Hybrid namely RML-98/RL-105, RML-5/RL-105, RML-4/NML-2 \& RML-95/RL-105 were superior hybrids, exhibited $>20 \%$ standard heterosis over check hybrids (CP-666 \& Rajkumar) for grain yield. Mid parent and better parent heterosis were higher in these hybrids for yield and yield attributing traits such as ear length, ear diameter, no of kernel row per ear, no of kernel per row and test weight. Therefore the findings of this study suggested that farmers to cultivate these hybrids for achieving higher maize production.

\section{ACKNOLEDGEMENTS}

The authors express their gratitude and sincere thanks to National Maize Research Program Rampur chitwan Nepal and Agriculture and Forestry University, Chitwan Nepal for their support for conducting research work. 
Journal of Maize Research and Development (2016) 2 (1): 123-132

ISSN: 2467-9291 (Print), 2467-9305 (Online)

DOI: http://dx.doi.org/10.3126/jmrd.v2i1.16223

\section{REFERENCES}

Abdel-Moneam, M.A, Attia, A.N, El-Emery, M.I., \& Fayed, E.A. (2009). Combining ability and heterosis for some agronomic traits in crosses of maize. Pakistan Journal of Biological Science, 12(5), 433-438.

Ali, A., Rahman, H., Shah, L., Shah, K.A., \& Rehman, S. (2014). Heterosis for grain yield and its attributing components in maize variety Azam using line $\times$ tester analysis method. Academia Journal of Agricultural Research, 2(11), 225-230.

Carangal, V.R., Ali, S.M., Koble, A.F., \& Rinke, E.H. (1971). Comparison of S1 with testcross evaluation for recurrent selection in maize. Crop Science, 11, 658-661.

Falconer, D.S., \& Mackay, T.F.C. (1996). Introduction to quantitative genetics. 4th ed. Longman, London.

Flint-Garcia, S.A., Buckler, E.S., Tiffin, P., Ersoz, E., \& Springer, N.M. (2009) Heterosis is prevalent for multiple traits in diverse maize germplasm. PLOS ONE, 4, e7433.10.1371/journal.pone.0007433

Gadad, S.K. (2003). Genetic analysis for quantitative traits, starch and oil in single cross hybrids of maize (Zea mays L.). M.Sc.(Agri.) Thesis, University of Agricultural Sciences, Dharwad, India.

Gurung, D.B. (2006). Genetic diversity, heterosis and combining ability within Nepalese maize varieties. Thesis, Ph.D. Central Luzon State University, Science of Munoz, Nueva Ecija, Philippines. $171 \mathrm{p}$.

Gurung, D. B., Upadhyay, S. R., Pandey, B. R., Pokhrel, B. B., \& Kshetri, J. B. (2011). Hybrid maize seed production: A new initiative for reliable and sustainable hybrid maize seed supply. Nepal Agriculture Development Journal 8, 1-8.

Hallauer, A.R., \& Miranda, J.B. (1988). Quantitative Genetics in Maize Breeding. 2nd ed. Iowa State University Press, Iowa, Ames. USA.

Koirala, K. B., Gurung, D. B., Kunwar, C. B., Tripathi, M., Thakur, P., Bhandari, G., Bhandari, B., Shrestha, J., Karki, T. B., Baral, B. R., Adhikari, P., Achhami, B. B., BK, S. B., Bhurer, K. P., Chaudhary, B. N., \& Chhetri, J. B. (2013). Evaluation of multinational companies' maize hybrids during winter season of 2010-2012. Proceedings of the 27th National Summer Crops Workshop 2.

Malik, Y., Malik, S.I., \& Javed, H.I. (2004). Estimates of heterosis among temperate, subtropical and tropical maize germplasm. Asian Journal of Plant Science, 3(1), 610.

MoAD. (2015). Statistical Information on Nepalese Agriculture 2012/13. Government of Nepal, Ministry of Agriculture and Cooperatives. Agri-business Promotion and Statistics Division. Singha Durbar, Kathmandu, Nepal.

Ordas, A. (1991). Heterosis in crosses between American and Spanish populations of corn. Crop Science, 31, 931-935.

Rosa, A., Leon, H., Martinez, G., \& Rincon, F. (2002). Heterosis, combining ability and genetic diversity in commercial hybrids of maize. Agronomia Mesoamerica, 11,113-122.

Russel, F., \& Eisensmith, S. P. (1983). MSTAT-C. Crop and Soil Sci. Deptt. Michigan State Univ. USA. 1983.

Semel, Y., Nissenbaum, J., Menda, N., Zinder, M., Krieger, U., Issman, N., Pleban, T., Lippman, Z., Gur, A., \& Zamir, D. (2006). Over dominant quantitative trait loci for yield and fitness in tomato. Proceedings of Natural Academia Science USA, 103, 12981-12986. 
Shrestha, J., Gurung D.B., \& Rijal, T.R. (2011). Determination of heterosis for grain yield in maize hybrids in Nepal. International Research Journal of Applied and Basic Sciences, 2 (6), 233-238, retrived from: http://www. irjabs.com.

Shrestha, J., Koirala, K., Katuwal, R., Dhami, N., Pokhrel, B., Ghimire, B., Prasai, H., Paudel, A., Pokhrel, K., \& KC, G. (2015). Performance evaluation of quality protein maize genotypes across various maize production agro ecologies of Nepal. Journal of Maize Research and Development, 1(1), 21-27. doi:http://dx.doi.org/10.3126/jmrd.v1i1.14241.

Yan, J.B., Warburton, M., \& Crouch, J. (2011) Association mapping for enhancing maize (Zea mays L.) genetic improvement. Crop Science, 51, 433-449. 